29 Klebanoff MA, Shiono PH, Rhoads GG. Outcomes of pregnancy in a national sample of resident physicians. N Engl f Med 1990;323:1040-5.

30 Beck NC Siegel LJ, Davidson NP, Kommier S, Bre preparation, anxiety and

31 Grennert L Persson PH, Gennser G. Benefits of ultrasonic screening of a pregnant population. Acta Obstet Gynecol Scand Suppl 1978;78(suppl):5-14.

32 Spencer B, Thomas H, Morris J. A randomised controlled trial of the provision of a social support service during pregnancy: the South Manchester Family Worker Project. Br F Obstet Gynaecol 1989;96:281-8.

\section{Microalbuminuria in chronic obstructive lung disease}

\section{R Wilkinson, J S Milledge, M J Landon}

Northwick Park Hospital,

HA1 3UJ

R Wilkinson, registrar

J S Milledge, consultant physician

\section{MRC Clinical Research Centre, Harrow, Middlesex HA1 3UJ}

M J Landon, scientific staff

\section{Correspondence to:}

Dr Milledge.

$B M \mathcal{F} 1993 ; 307: 239$ Harrow, Middlesex

Changes in renal function have been reported in chronic obstructive lung disease ${ }^{1}$ but not proteinuria. We describe a heterogeneous group of patients with chronic obstructive lung disease who were found to have microalbuminuria.

\section{Patients, methods, and results}

Twenty two inpatients with chronic obstructive lung disease provided a clean catch midstream specimen of urine. Twenty normal healthy volunteers matched for sex (two women in each group) and age (within two years) provided control samples. None had any medical history of renal disease.

Forced expiratory volume in one second and forced vital capacity were measured by standard spirometric methods and arterial blood gas values by Instrumentation Laboratory (UK) Blood Gas Analyser 3. Albumin was measured with pyrogallol red molybdate. $\gamma$-Glutamyltransferase, $\quad \beta$ - $N$-acetylglucosaminidase, and lysozyme values were measured by using commercially available substrates. Results of the urine analyses were expressed per mmol creatinine. As the results were not normally distributed, log transformed data were used for analysis. Two sample $t$ tests were used to compare the chronic obstructive lung disease and control groups, and the linear association between variables was assessed with Pearson correlation coefficients.

Patients with cor pulmonale Mean and SD - - - - Upper limit of reference range

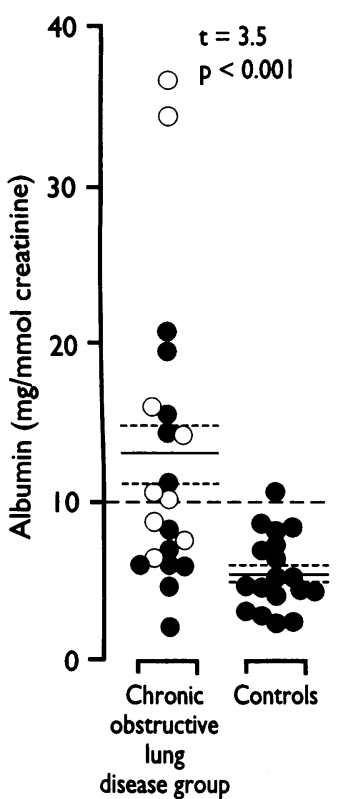

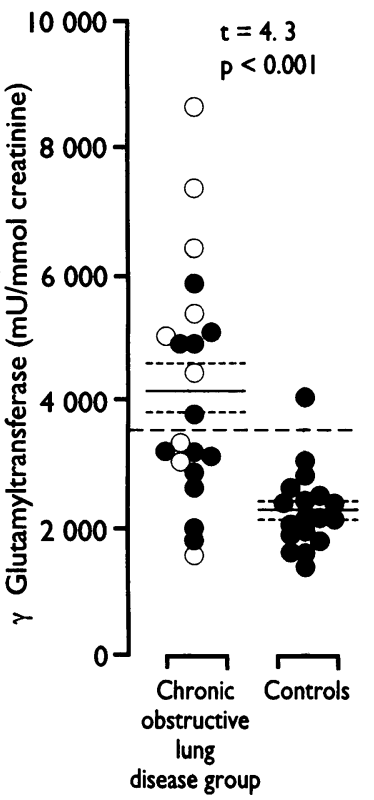

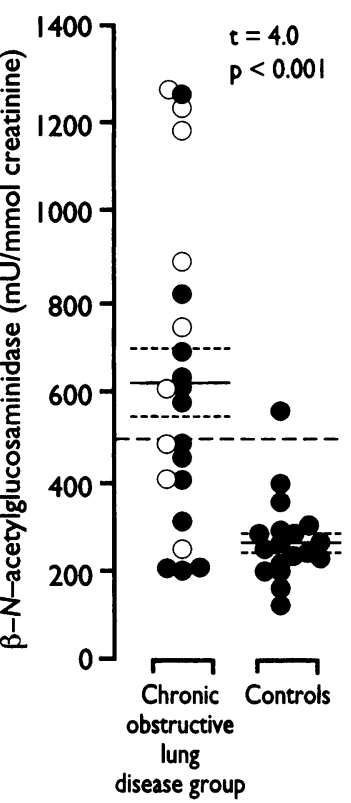

Urinary albumin $\gamma$-glutamyltransferase, and $\beta-N$-acetylglycosaminidase in patients with chronic obstructive lung disease and controls
33 Oakley A, Rajan L, Grant A. Social support and pregnancy outcome. Br F Obstet Gynaecol 1990;97:155-62.

34 Chalmers I, ed. Oxford database of perinatal trials. Oxford: Oxford University Press, 1988.

35 Vilar J, Farnot U, Barros F, Victora C, Langer A, Belizan JM. A randomized trial of psychosocial support during high-risk pregnancies. $N$ Engl $f$ Med 1992;327:1266-71.

(Accepted 13 May 1993)

The average age of the patients with chronic obstructive lung disease was 72 years (range 57-85), and the disease had been present for a mean of 20 years (range 2-50). Mean values for carbon dioxide tension and oxygen pressure were $5 \cdot 7$ (range $4 \cdot 2$ to $9 \cdot 3$ ) and $9 \cdot 1$ $(4 \cdot 9$ to $17 \cdot 1) \mathrm{kPa}$ respectively. Forced vital capacity averaged $1.8(0.6$ to 3.0$)$ litres, and forced expiratory volume in one second/forced vital capacity was $54 \%$ (28-91\%). Nine patients had clinical and electrocardiographic evidence of cor pulmonale.

No sample had evidence of haematuria, glycosuria, or lysozyme. The excretion of albumin was significantly higher in the chronic obstructive lung disease group. The distribution of $\gamma$-glutamyltransferase and $\beta-N$-acetylglucosaminidase levels was similar (figure). In the chronic obstructive lung disease group there was a highly significant relation between $\gamma$-glutamyltransferase and $\beta-N$-acetylglucosaminidase levels $(r=0.681$; $p=0.001$ ) but not between either of these levels and albumin. The excretion of these markers was not related to age, forced expiratory volume in one second, forced vital capacity, forced expiratory volume in one second/forced vital capacity, or arterial oxygen pressure, but there was a significant relation between arterial carbon dioxide tension and $\gamma$-glutamyltransferase level $(r=0.55 ; p=0.01)$. Patients with evidence of cor pulmonale did not form a distinct subgroup.

\section{Comment}

This preliminary study suggests that proteinuria may be a feature of chronic obstructive lung disease. On average the excretion was doubled, but there was a wide scatter of results; in half the patients values were normal. The appearance of albumin (a large protein) in the urine but the virtual absence of lysozyme (a small protein) suggests that the proteinuria is glomerular. A similar proteinuria has been described in chronic sleep apnoea and at high altitude. ${ }^{23}$ In both cases the protein leak was attributed to increased glomerular permeability as a result of tissue hypoxia. Whether this is so in chronic obstructive lung disease is not known.

In chronic obstructive lung disease both atrial natriuretic peptide ${ }^{4}$ and glomerular size ${ }^{5}$ are increased, which would favour increased filtration. Polypharmacy is common but the renal effect is difficult to assess and impossible to control. There was no unique combination of drugs or class of drugs associated with high renal loss of albumin or enzymes. The enzymuria may reflect tissue hypoxia, renal hypertrophy, or smoking history.

Further longitudinal studies are needed to determine whether these changes are progressive or have any prognostic relevance.

1 Daggett P. An investigation of renal function in chronic bronchitis. Postgrad Med f 1977;53:24-7.

2 Sklar AH, Chaudhery BA. Reversible proteinuria in obstructive sleep apnea syndrome. Arch Intern Med 1988;148:87-9.

3 Winterborn MH, Bradwell AR, Chessner IM, Jones GT. The origin of the proteinuria at high altitude. Postgrad Med $\mathcal{f}$ 1987;63:179-81.

4 Stewart AG, Bardsley PA, Baudouin SV, Waterhouse JC, Thompson JS, Morrice AH, et al. Changes in atrial natriuretic peptide concentrations during intravenous saline infusion in hypoxic cor pulmonale. Thorax 1991;46: 829-34.

5 Campbell LJ, Calverley PM, Lamb D, Flenley DC. The renal glomerulus in hypoxic cor pulmonale. Thorax 1982;37:607-11.

(Accepted 13 May 1993) 